\title{
Digital and Web Content Accessibility for Persons with Disabilities: A case study of Indian open universities
}

Akhilesh Kumar ( $\square$ akumar@vmou.ac.in )

Vardhaman Mahaveer Open University https://orcid.org/0000-0002-0141-6388

\section{Research Article}

Keywords: Open and Distance Learning, Information and Communication Technologies, Digital Accessibility, WCAG Guidelines, GIGW Guidelines

Posted Date: August 13th, 2021

DOI: https://doi.org/10.21203/rs.3.rs-772144/v1

License: (a) (1) This work is licensed under a Creative Commons Attribution 4.0 International License. Read Full License 


\section{Abstract}

The radical development of internet and other Information and Communication Technologies have changed the scenario of education system in general and open and distance learning in particular which was further accelerated by the recent COVID-19 pandemic. Information and Communication Technology (ICT) tools now a days are pivotal to any Open and Distance Learning (ODL) system. With the growth of ICT based education the issue of accessibility of digital information has also gained the attention of intelligentsia. With the interference of ICT tools, discussions have been taking place about the digital accessibility of web-based information available over websites. Websites of Open Universities are central source of educational and administrative information and learning for a learner enrolled in open and distance learning system. Further the basic promise of an open and distance learning system is providing education for marginalized group too and thus it must be as per the needs of persons with disabilities which has been recommended by United Nations Convention on Rights of Persons with Disabilities (UNCRPD). An enquiry has been made in present research to study primary accessibility features Screen Reader Access, High Contrast Text, Word Spacing, Text Resize feature and the feature of language change available over websites of Indian Open Universities. It was observed that about $45 \%$ of Indian Open University websites lacks any such accessibility features. Remaining $55 \%$ open universities of India, mostly were found providing two to four out of these five accessibility mechanisms required for persons with disabilities on any website. As Government of India has developed Guidelines for Indian Government Websites (GIGW) which has advised government institutions to confirm their websites in compliance with Web Content Accessibility Guidelines (WCAG 2.0) guidelines of World Wide Web Consortium (W3C) at 'AA' level. The preliminary study revealed that Indian Open Universities has long way to go to make their websites GIGW \& WCAG 2.0 complaint in order to ensure digital accessibility in higher education through open and distance learning for persons with disabilities to ensure inclusion in higher education in India.

\section{Introduction}

The evolution of internet and other related technologies was a revolution which has changed human life to a greater extent. The emergence of internet and other Information and Communication Technologies has made human life easier and up to certain extent made those things possible which were supposed very difficult otherwise, if not impossible, four decades back. Internet has a significant contribution in making the world a global village. Internet and the Information and Communication technologies have penetrated in all human activities whether its banking, finance, education, medical or any human activity and for the majority who have access to ICT (in particular, computers and the Internet) there are a number of clear economic, educational, social and health-related advantages (Macdonald \& Clayton, 2013). It has made the human to human or machine to machine or machine to human interaction faster and very easier.

Internet access has many advantages for its users. For the users of the Internet, it is like a virtual world in their hand through which they can perform many activities with the help of many different devices either a big computer system or a handheld device. For example, the popularity of online shopping could be taken. A user of internet has a variety of choices to purchase certain things from anywhere in the world where as a nonuser of internet is deprived of such advantages. Another recent example may be taken the COVID-19 vaccination. When COVID-19 vaccination was made available through its slot booking online, many non-users of internet due to any reason either lack of knowledge or lack of devices were deprived from the vaccination. In fact, a non-user of internet due to any reason is impoverished of its benefits. It is the advantage of internet that it welcomes its users and opens several countless avenues and make things easier for the person but on the other hand it is a big disadvantage of internet and other ICT based tools that these exclude the non-users from many benefits and advantages.

Such non-users of the internet could be classified in two broad categories: first such non-user of internet may be a person who does not have internet available and the second may be such a person who might have internet available but due to some of the limitations either physiological or environmental, it is not accessible for them. For those non-users who do not have internet available, the only solution is to make it available to them but for those non-users who could not use internet despite of its availability, the solution is to improve accessibility of internet-based information system by using ICT based tools and new developments. Such digital divide (Dobransky \& Hargittai, 2006) or sometimes referred to as digital exclusion (Macdonald \& Clayton, 2013) could be reduced by making the internet and the information available over internet in accessible format to a maximum possible extent. Persons with disabilities form a larger group of non-user of internet, not due to non-availability of internet but due to inaccessible formats of information available over internet usually referred as disability digital divide (Dobransky \& Hargittai, 2006) and could be described as discrepancies in rates of physical access to computers and the Internet between people with and without disabilities(Gorski \& Clark, 2002).

With the development of Information and Communication Technologies, the accessibility of web-based information has taken the global attention and several international as well as national guidelines have been prepared in order to make websites accessible for persons with disabilities as around $5 \%$ population of the world experience some form of disability. The United Nations Convention on Rights of Persons with Disabilities (UNCRPD) 2006 is a mile stone in world history of disability rights. The article 9 of UNCRPD (2006) deals with accessibility issues in general and includes provisions of accessibility of web-based resources and information in particular. It recommends that

"States Parties shall also take appropriate measures to promote access for persons with disabilities to new information and communications technologies and systems, including the Internet and to promote the design, development, production and distribution of accessible information 
and communications technologies and systems at an early stage, so that these technologies and systems become accessible at minimum cost" (UNCRPD, 2006, Article 9, Section g \& h).

The big move in this area has been made by World Wide Web Consortium popularly known as 'W3C' which released Web Content Accessibility Guidelines (WCAG) and measures of its compliance at various levels. Web Content Accessibility Guidelines (WCAG) 2.0 is a very comprehensive set of principles of developing and designing websites to ensure universal accessibility and for making Web content more accessible for persons with disabilities and also to elderly people with several types of sensory losses due to age factor(Ribera et al., 2009). The purpose of WCAG 2.0 is based on the principles of universal design which could benefit all including persons with disabilities which and organized around the four core principles which are: Perceivability, Operability, Understandable and Robust (WCAG 2.0). It has been adapted by many counties and in accordance with WCAG 2.0, Guidelines for Indian Government Websites (GIGW) version 2.0 has been prepared by National Informatics Centre (NIC), the second edition of which is released in 2019. GIGW (2019) defines Web-Accessibility as

"Web accessibility means that people with disabilities can also perceive, understand, navigate, and interact with the Web, and that they can contribute to the Web. It encompasses all disabilities that affect access to the Web, including visual, auditory, physical, speech, cognitive, and neurological disabilities" (GIGW, 2019).

Further it affirms that the Websites and apps should be designed and developed in such way that they are accessible by all people, whatever may be their hardware, software, language, culture, location, or physical or mental ability. The GIGW 2019 is prepared by the NIC of India has taken in to account not only the World Wide Web Consortium's (W3C's) Web Content Accessibility Guidelines (WCAG 2.0), but also the provisions of Rights of Persons with Disabilities Act 2016 (GIGW, 2019). The Rights of Persons with Disabilities Act 2016, enacted in India in 2017 is a very comprehensive act dealing with disability rights. The Sect. 42 of Rights of Persons With Disabilities (RPWD) Act of India mentions that

"The appropriate Government shall take measures to ensure that.

i. all contents available in audio, print and electronic media are in accessible format;

ii. persons with disabilities have access to electronic media by providing audio description, sign language interpretation and close captioning;

iii. electronic goods and equipment which are meant for everyday use are available in universal design (RPWD Act, 2016)".

Despite several international as well as national guidelines on web-accessibility, the universal accessibility of web based information remains a major challenge for both web developers and accessibility researchers. Conformance of WCAG 2.0 guidelines by web pages is a significant factor in measuring universal accessibility(Ismail \& Kuppusamy, 2018).

Profound impact of Internet and other ICT tools on education systems has been reported across the world (Renes \& Strange, 2011) and multiplied by COVID-10 pandemic situation. ICT tools have made their strong presence in education system regardless of the nature of education either informal, formal or non-formal and during COVID-19 period entire world recognized the power of Internet and ICT tools in providing education to all learners while remain at home. It has given educational opportunities to everyone who is interested and brought out the education from several boundaries of geography, time, pace and so on. ICT is presented as a solution for all contemporary education and training problems (Martin, 2008). The technology has been advancing rapidly and recently and it has become inevitable to use technology in the education sector. Because of this central importance of ICT and Internet it has become necessary to re-organize the education sector (Cavus, 2015) with an optimal blend of pedagogy and accessible technology.

The ongoing revolutionary changes in Information and Communication Technologies has transformed the entire Open and Distance Learning Systems too (Arulogun et al., 2020; Cavus, 2015; Guri-Rosenblit, 2005; Renes \& Strange, 2011; Stošić, 2015; Weidlich \& Bastiaens, 2018) which is well documented in contemporary research studies. Many researchers now a days started defining distance learning or distance education as a system of education which usually takes place over the internet mediated by ICT tools(Milman, 2015; Weidlich \& Bastiaens, 2018).Even since its emergence, ICT tools brought up new generation of distance learning(Guri-Rosenblit, 2005) which is further reinforced dramatically by COVID-19 pandemic situation during which entire world realized the power of ICT tools like never before(Dhawan, 2020; Dwivedi et al., 2020; Thomas \& Rogers, 2020). The degree of popularity of ICT tools can be understood as some countries have replaced face-to-face education with distance education in response to the coronavirus(Al Lily et al., 2020). Oladokun \& Aina, 2011 noted that Open and distance learning (ODL) has created room for the emergence of virtual education.

The major benefit of ICT tools-based learning is the convenience to use i.e., using ICT tools one can get one's studies anywhere and everywhere. It also removes the geographical boundaries of village city state or even countries. ICT tools enable learners to learn through their own pace and unlike traditional face to face education, it is easier for learners to replay or replicate the content, to store the content and to retrieve the content with more ease. In modern era of education the application of modern educational ICTs have a major role to play(Oladokun \& Aina, 2011) which is

Page 3/8 
more significant if it is the case of education through open and distance learning. Open and Distance Learning (ODL) students rely majorly on the use of Information, Communication and Technology (ICT) tools for online facilitation and other activities supporting learning (Arulogun et al., 2020)

Internet based resources in general and websites of open universities in particular play a major role in communication with learners as websites are the easiest way to find out any information, to communicate with the university, to get enrolled, to raise grievences, to access multimedia based material related to the programme, to get responses on queries, to access self-learning materials, to get information related to examination and many more. Many a times the first impression about an organization (and so is the Open and Distance Learning Institutions too) is almost always based on its Web site(Ismailova \& Kimsanova, 2017). Websites (of open universities) are also being used as a tool for inter- and intraorganizational exchange(Astani \& Elhindi, 2008) and usually a primary medium of information dissemination(Ismail \& Kuppusamy, 2018; Lawrence \& Giles, 1999; Potter, 2002) because of their effectiveness, efficiency, and engagement(Keller, 2008). In present scenario students of Open and Distance Learning are mostly dependent on the website of open universities and Information and Communication Technology systems of the higher education institution(Arulogun et al., 2020); whether it is instructional aspects, curriculum transactions, student's support, grievance redressal, examination or assignment submission, a student has to be ICT-smart for being a learner of distance education system.

One pivotal aspect which advocates the need of accessible website of open and distance learning system is that the emergence of and development of Open and Distance Learning system was reinforced since its inception, to provide education to those who cannot attend regular face-to-face classes due to any reason or belong to marginalized sections including persons with disabilities, persons from poor socio-economic status or marginalized group of learners due to any other reason but a very large percentages of web sites of open and Distance Learning institutions as well as higher education institutions still continue to be inaccessible to people with disabilities. As tools and guidelines are available to evaluate and help designers and webmasters in making their web sites accessible, it is unclear why so many sites continue to be inaccessible(Lazar et al., 2004). Research has shown that people with disabilities are most at risk of being excluded from access, and in particular people who are blind or visually impaired and who use assistive technologies such as screen readers(Brophy \& Craven, 2007) are at a greater risk of deprived from higher education due to inaccessible websites of open and distance learning higher education institutions.

\section{Objectives Of The Study}

Gradually the study of accessibility of universities websites has gained attention of researchers across the world(Astani,Marzie; Elhindi, 2008; Ismailova \& Kimsanova, 2017) and also it has gained attention of few researchers in India(Ismail \& Kuppusamy, 2018) but studies focusing accessibility of websites of open universities in general and open universities of India in particular were not found in contemporary literature. It is pertinent here to mention that accessibility of websites is more critical in the case of open universities than the conventional and regular one as learners of open universities get most of their learning resources from the websites of respective open universities. Also, open and distance learning fosters the larger population of marginalized group i.e. drop outs, persons with disabilities etc.

As the hallmark feature of open and distance learning is to provide education to all in general and to foster the educational needs of the marginalized group of learners in particular, the success of an open university depends upon the accessibility features available over its website based on the principle of universal design. The present study was intended to find out the extent to which websites of Indian Open Universities are accessible enabling a learner with disability to find out the desired information and to get benefitted from open and distance learning.

\section{Methods}

SAMPLE: The home page of websites of all fifteen open universities of India including one national open university: Indira Gandhi National Open University (IGNOU) and fourteen state open universities served as sample for this study. The websites of all fifteen open universities of India were investigated based on availability of primary features of accessibility which were the option of Text Resize, High Contrast Text, Screen Reader Access, Option of Word Spacing and Language Choice Options. The language choice option has been taken in to account considering rich language diversity of Indian learners.

METHODOLOGY: It was a preliminary qualitative study on accessibility features of websites of Indian open universities. The websites of all fifteen open universities were investigated manually to get the idea of primary accessibility features available on home page of their respective web sites. Five digital accessibility features were taken in to account for the present study which were Text Resize, High Contrast Text, Screen Reader, Word Spacing and options of Language Choice. The screenshot of home pages of all open universities was preserved by taking screenshot of the website of open universities.

\section{DATA COLLECTION AND ANALYSIS}

The home pages of all open universities of India were visited by me and a qualitative assessment of their accessibility features were made. All the five criteria were assessed and recorded. The following websites were visited and assessed for this study: 


\begin{tabular}{|c|c|c|}
\hline SI No & Name of the Open University & URL of Home Page \\
\hline 1 & Indira Gandhi National Open University (IGNOU), New Delhi & http://ignou.ac.in/ \\
\hline 2 & Netaji Subhash Open University, West Bengal & http://www.wbnsou.ac.in/ \\
\hline 3 & Nalanda Open University, Patna & http://www.nalandaopenuniversity.com/ \\
\hline 4 & Orissa State Open University, Sambalpur, Orissa & https://www.osou.ac.in/ \\
\hline 5 & Bhimrao Ambedkar Open University Hyderabad & https://braou.ac.in/ \\
\hline 6 & Bhimrao Ambedkar Open University Ahmedabad & https://baou.edu.in// \\
\hline 7 & Krishnakanta Handiqui State Open University of Assam (KKHSOU) & http://www.kkhsou.in/web_new/ \\
\hline 8 & Uttrakhand Open University, Haldwani & https://www.uou.ac.in/ \\
\hline 9 & Madhya Pradesh Bhoj Open University, Bhopal & http://mpbou.edu.in/ \\
\hline 10 & Yashwant Rao Chavhan Open University, Nasik & https://www.ycmou.ac.in/ \\
\hline 11 & Tamilnadu Open University, Chennai & http://www.tnou.ac.in/ \\
\hline 12 & Pandit Sundarlal Sharma State Open University Chattishgarh & http://pssou.ac.in/ \\
\hline 13 & Karnataka State Open University, Karnaktaka & https://ksoumysuru.ac.in/ \\
\hline 14 & Uttar Pradesh Rajarshi Tandon Open University, Allahabad & http://www.uprtou.ac.in/ \\
\hline 15 & Vardhman Mahaveeer Open University, Kota & https://www.vmou.ac.in/ \\
\hline
\end{tabular}

\section{FINDINGS:}

As indicated in figure 1, the widely used accessibility feature was screen reader access which was available over websites of $40 \%$ of the open universities. Further when it was examined in depth all of them were not screen reader enabled rather all provided links of screen reader software on their websites, however now a days it is possible to make a website with screen reader access in one click.

The word spacing feature was used only by $6 \%$ of open universities of India and the option of change in at least two languages were available on websites of $33 \%$ open universities only with a choice of the English and Hindi.

Out of total fifteen open universities in India, dedicated to only Open and Distance Learning seven around $47 \%$ of open universities of India had no accessibility features available on their home page whereas $53 \%$ of open universities in India had at least on accessibility features out five features under consideration was available over their websites.

Further. a closer look on data revealed that about $46 \%$ of open universities i.e., about half the total no of open universities in India have inaccessible websites. Out of the five selected primary features of an accessible website it was observed that websites of two state open universities have only one accessibility features out of 5 features, Websites of three open universities were found having met with 2 criteria of accessibility out of 5 criteria taken for assessment and there were two open universities meeting 3 criteria and there was only one open university met with 4 criteria out of 5 accessibility criteria taken for the study. None of Indian open universities were found having all the five accessibility features on their websites considered in present study. If we give equal weightage of 20 Marks to all criteria taken for consideration, seven open universities scored 0. Two open universities scored 20 marks and two open universities have a score of $40 \%$, two open universities scored $60 \%$ and there is only one open university which could score $80 \%$ on the laid down criteria in present study. Only three open universities are there (20\%) out of 15 open universities in India were found meeting at least three criteria of accessibility taken for this study.

\section{Discussions \& Conclusions}

Here the question arises why websites of Indian Open Universities have poor accessibility features despite the several guidelines like GIGW and RPWD Act 2016? The possible answer is that the regulatory bodies of higher education, particularly meant for Open and Distance learning have not given sufficient weightage to the accessibility features particularly accessibility of the web-based information. Recently developed accreditation framework for ODL by National Assessment and Accreditation Council (NAAC) in India has included Accessible Website as a sub indicator of accessibility feature with a weightage of 5 marks for entire accessibility features including buildings. Digital accessibility has not been given due importance for assessment and accreditation of institutions. The Criteria VII of NAAC Manual (2019) titled Institutional Values and Best Practices of 100 Marks includes Key Indicators 7.1 which is 'Key Values and Social Responsibilities' of 50 Marks out of which point No 84 ,

Page 5/8 
Indicator 7.1.3 includes number of disabled friendly amnesties of 5 Marks (NAAC, 2019). It is interesting to note here that Open and Distance Learning promises learners lesser face to face interaction and more ICT based interaction. In such a situation, although accessibility of physical infrastructure is also important, it is more important for Open Universities to have a disabled-friendly accessible websites and the digital contents. Thus, giving more weightage to digital accessibility and making this a separate essential indicator for NAAC grading of open universities may improve the situation.

Another framework of Ranking of higher education institution National Institutional Ranking Framework has been developed by the regulator of higher education in India the University Grants Commission. In this ranking framework the criteria 4 'Out Reach and Inclusivity' has been given only $10 \%$ weightage. Within this, out of 100 marks 20 marks has been given for facilities for Economically and Socially Challenged Students and 20 Marks for Facilities for Physically Challenged Students (PCS). Combining these two criteria of inclusivity and the weightage given to these two in institutional ranking yields overall $4 \%$ contribution in Institutional ranking with no separate option of digital accessibility and accessibility of webbased information. First of all, the weightage given to this component is not consistent with the promise of Govt of India to provide inclusive higher education and furthermore it has no separate provision of digital accessibility feature of the institution. The UGC need to think more weightage to Inclusivity features of universities within which digital accessibility should be separated from physical accessibility at least in the case of open universities.

\section{Conclusion:}

With the development of tools of information and communication technologies, growing interest of educators has been observed about the accessibility of several websites which is very crucial in case of open and distance learning system. Globally it has been taken in to account to make the education inclusive, particularly higher education system. Although the government of India has issued guidelines to make websites of higher education institutions accessible for persons with disabilities, still the websites of open universities of India lacks basic accessibility features. Present study carried out considering 5 basic accessibility features Screen Reader, High Contrast Text, Word Spacing, Text Resize feature and the feature of language change and it was observed that in case of Indian Open Universities, digital accessibility needs to be improved to a greater extent as students of open universities rely heavily on ICT tools for various information and learning needs available through the websites of open universities. Indian open universities have miles to go to achieve WCAG 2.0 guidelines at 'AA' standard as promised by GIGW framework of govt of India.

\section{Declarations}

Authors declare that there is no competing interests.

\section{References}

Al Lily, A.E., Ismail, A.F., Abunasser, F.M., Alhajhoj Alqahtani, R.H.: Distance education as a response to pandemics: Coronavirus and Arab culture. Technol. Soc. 63, 101317 (2020). https://doi.org/10.1016/j.techsoc.2020.101317

Arulogun, O.T., Akande, O.N., Akindele, A.T., Badmus, T.A.: Survey dataset on open and distance learning students' intention to use social media and emerging technologies for online facilitation. Data in Brief. 31, 105929 (2020). https://doi.org/10.1016/j.dib.2020.105929

Astani,Marzie; Elhindi, M.A. (2008). An Empirical Study of University Websites. Issues In Information Systems, ix(2), $460-465$.

https://iacis.org/iis/2008/S2008_1077.pdf

Brophy, P., Craven, J.: Web Accessibility. Library Trends. 55(4), 950-972 (2007). https://doi.org/10.1353/lib.2007.0029

Cavus, N.: Distance Learning and Learning Management Systems. Procedia - Social and Behavioral Sciences. 191, $872-877$ (2015). https://doi.org/10.1016/j.sbspro.2015.04.611

Dhawan, S.: Online Learning: A Panacea in the Time of COVID-19 Crisis. Journal of Educational Technology Systems. 49(1), 5-22 (2020). https://doi.org/10.1177/0047239520934018

Dobransky, K., Hargittai, E.: The disability divide in internet access and use. Information Communication and Society. 9(3), 313-334 (2006). https://doi.org/10.1080/13691180600751298

Dwivedi, Y.K., Hughes, D.L., Coombs, C., Constantiou, I., Duan, Y., Edwards, J.S., Gupta, B., Lal, B., Misra, S., Prashant, P., Raman, R., Rana, N.P., Sharma, S.K., Upadhyay, N.: Impact of COVID-19 pandemic on information management research and practice: Transforming education, work and life. Int. J. Inf. Manage. 55, 102211 (2020). https://doi.org/10.1016/j.ijinfomgt.2020.102211

Gorski, P., Clark, C.: Multicultural Education and the Digital Divide: Focus on Disability. Multicultural Perspectives. 4(4), 28-36 (2002). https://doi.org/10.1207/S15327892MCP0404_6 
Guri-Rosenblit, S.: (2005). “Distance education” and "e-learning”: Not the same thing. In Higher Education. https://doi.org/10.1007/s10734-0040040-0

Ismail, A., Kuppusamy, K.S.: Accessibility of Indian universities' homepages: An exploratory study. Journal of King Saud University - Computer and Information Sciences. 30(2), 268-278 (2018). https://doi.org/10.1016/j.jksuci.2016.06.006

Ismailova, R., Kimsanova, G.: Universities of the Kyrgyz Republic on the Web: accessibility and usability. Univ. Access Inf. Soc. 16(4), 1017-1025 (2017). https://doi.org/10.1007/s10209-016-0481-0

Keller, J.M.: (2008). First principles of motivation to learn and e3-learning. Distance Education. https://doi.org/10.1080/01587910802154970

Lawrence, S., Giles, C.L.: Accessibility of information on the web. Nature. 400(6740), 107-107 (1999). https://doi.org/10.1038/21987

Lazar, J., Dudley-Sponaugle, A., Greenidge, K.-D.: Improving web accessibility: a study of webmaster perceptions. Comput. Hum. Behav. 20(2), 269288 (2004). https://doi.org/10.1016/j.chb.2003.10.018

Macdonald, S.J., Clayton, J.: (2013a). Back to the future, disability and the digital divide. Disability and Society.

https://doi.org/10.1080/09687599.2012.732538

Macdonald, S.J., Clayton, J.: Back to the future, disability and the digital divide. Disability \& Society. 28(5), 702-718 (2013b).

https://doi.org/10.1080/09687599.2012.732538

Milman, N.B.: (2015). Distance Education. In International Encyclopedia of the Social \& Behavioral Sciences (pp. 567-570). Elsevier. https://doi.org/10.1016/B978-0-08-097086-8.92001-4

Oladokun, O., Aina, L.: ODL and the impact of digital divide on information access in Botswana. The International Review of Research in Open and Distributed Learning. 12(6), 157 (2011). https://doi.org/10.19173/irrodl.v12i6.1053

Potter, A.: Accessibility of Alabama government Web sites. Journal of Government Information. 29(5), 303-317 (2002).

https://doi.org/10.1016/S1352-0237(03)00053-4

Renes, S.L., Strange, A.T.: Using Technology to Enhance Higher Education. Innov. High. Educ. 36(3), 203-213 (2011).

https://doi.org/10.1007/s10755-010-9167-3

Ribera, M., Porras, M., Boldu, M., Termens, M., Sule, A., Paris, P.: (2009). Web Content Accessibility Guidelines 2.0. Program. https://doi.org/10.1108/00330330910998048

Stošić, L.: (2015). THE IMPORTANCE OF EDUCATIONAL TECHNOLOGY IN TEACHING. International Journal of Cognitive Research in Science, Engineering and Education, 3(1), 111-114. https://doi.org/10.23947/2334-8496-2015-3-1-111-114

Thomas, M.S.C., Rogers, C.: Education, the science of learning, and the COVID-19 crisis. PROSPECTS. 49(1-2), 87-90 (2020). https://doi.org/10.1007/s11125-020-09468-z

Weidlich, J., Bastiaens, T.J.: (2018). Technology Matters - The Impact of Transactional Distance on Satisfaction in Online Distance Learning. The International Review of Research in Open and Distributed Learning, 19(3). https://doi.org/10.19173/irrodl.v19i3.3417

MSJ \& E: (2016) The Rights of Persons with Disabilities Act, retrieved from

https://www.ncpedp.org/sites/all/themes/marinelli/documents/Rights\%20of\%20Persons\%20with\%20Disabilities\%20(RPWD)\%20Act\%202016.pdf

Gol: (2019) GIGW Manual retrieved from https://web.guidelines.gov.in/assets/gigw-manual.pdf

NAAC: (2019) Assessment and Accreditation Manual for Open Universities retrieved from http://www.naac.gov.in/images/docs/Manuals/ODLManual-22_04_2019.pdf

\section{Figures}




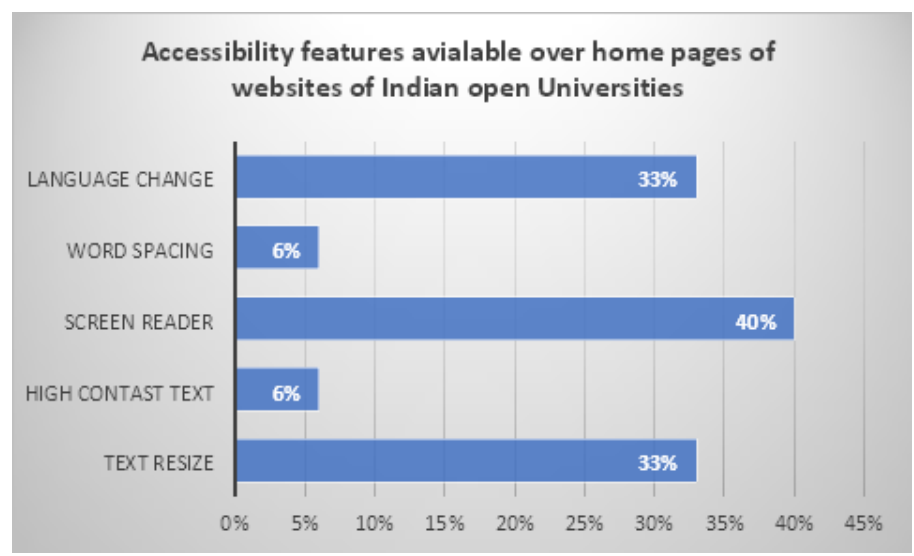

\section{Figure 1}

Accessibility features available over the website of open universities

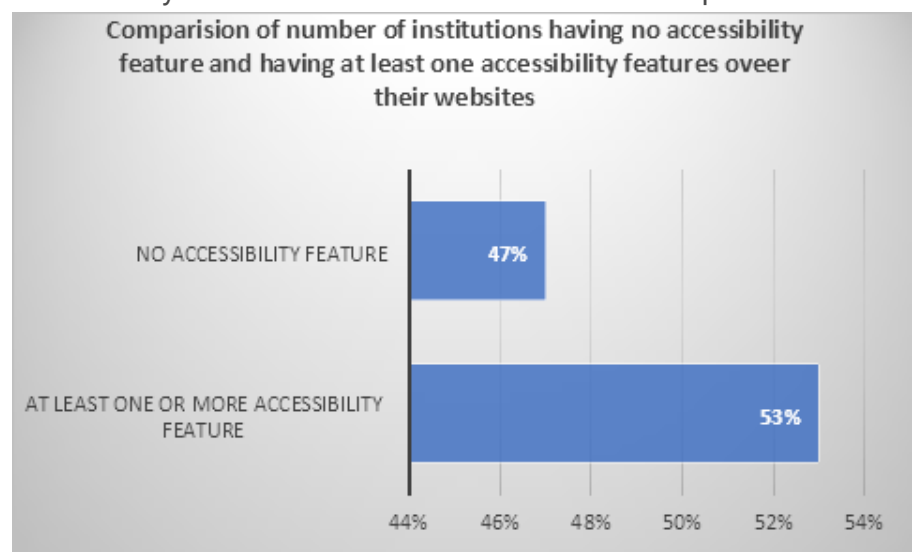

\section{Figure 2}

Comparison of number of institutions having no accessibility features and having at least one accessibility features over their websites 